EPiC Series in Built Environment
Volume 1, 2020, Pages 390-399
Associated Schools of Construction Proceed-
ings of the 56th Annual International Conference

\title{
Pilot Study for Understanding a Contributing Factor for a Decrease in Skilled Construction Labor
}

\author{
Brent Buckner, MSCM \\ Fowler General Construction \\ Richland, WA
}

\author{
Bill Bender, PhD, PE, LEED AP \\ University of Washington \\ Seattle, WA
}

\begin{abstract}
The construction industry has and will continue to see skilled labor shortages. The most critical shortage of staffing is at the building level, which is comprised of skilled construction craft workers. Societal pressures for higher education appear to exacerbate this shortage. To further understand the decrease of skilled construction labor, a pilot study of 53 high school students was conducted. The survey was conducted on 17 to 18 year-old students who will be graduating high school within the next one to two years. The results of the survey point to the societal view that higher education is of utmost importance to students and their families. Furthermore, the results showed that construction is not given positive consideration or seen as a valuable alternative to higher education. Parents and children deem the pursuit of higher education as the way to become financially successful and have a rewarding career.
\end{abstract}

Key Words: Work force development, Labor, Careers, Construction jobs

\section{Introduction}

With the construction industry booming in parts of the country, the need for skilled labor is at the forefront of many discussions. It may be that construction is experiencing a slight decline in individuals' willingness to join the industry. Within the past five to ten years, this downward trend appears to have become more apparent. To understand this issue, we performed a pilot study on a small set of young adults to help understand if going to college is more important than going to work in the field. We also hope to understand what is causing the construction craft profession to be negatively viewed by young adults.

This paper focuses on the factors that are contributing to the shortage of construction workers, the issues young adults face while debating which direction to take their career after high school, and why students are not choosing to join apprenticeship programs through union or nonunion construction trades. The questionnaire contained within this study was conducted confidentially.

The objectives of this paper are to utilize a small set of data to develop a case around the theme of why young people are not interested in construction as a profession. The authors understand that the 
Pilot Study for Understanding a Contributing Factor for a Decrease in ... W. Bender and B. Buckner

results of this pilot study are extremely limited and only indicate views from a particular high school in a particular part of the country. Using this initial set of data, we will develop future studies to develop a larger set of data.

\section{Construction Increase and Skilled Construction Labor Decrease}

The construction industry continues to grow at a rapid rate. The Unites States government has delivered the 2019 budget for infrastructure adding 1.5 trillion dollars for current and future infrastructure projects (Rebuilding Americas Infrastructure, 2019). In addition to the infrastructure rebuild, construction spending has increased drastically. Figure 1 below shows the increase of construction spending from years 2000-2018. In the year 2000, construction spending amounted to slightly above 800 billion dollars, increasing to 1,375 billion dollars in 2018; this is an increase of $75 \%$ percent in 18 years (Construction Spending, 2018).

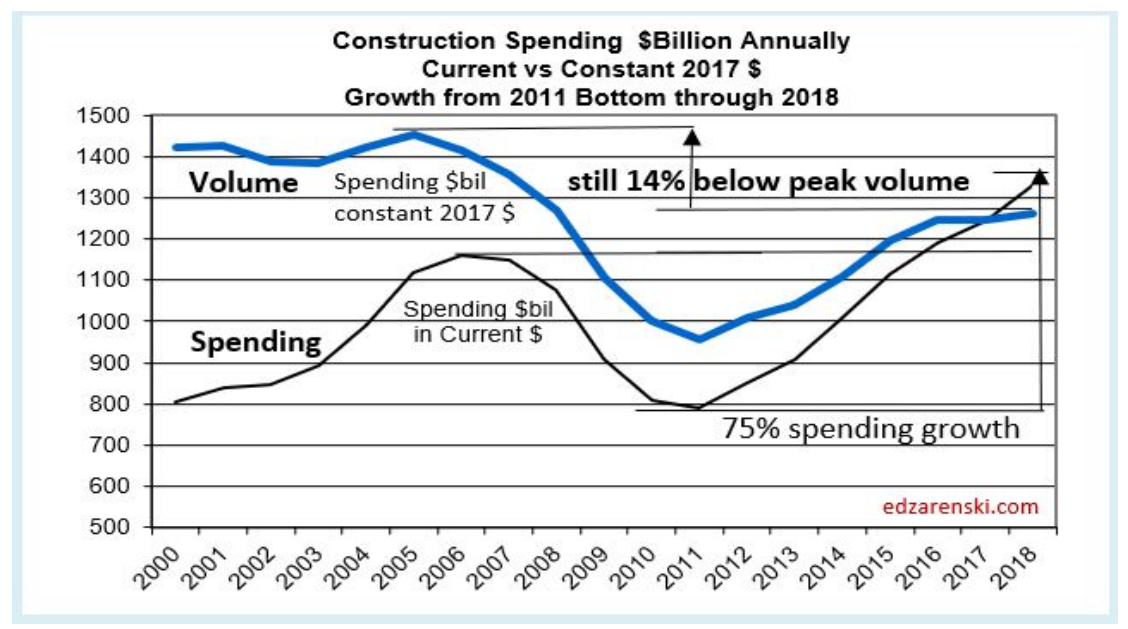

Figure 1 Annual Construction Spending

A construction labor shortage has emerged within the last few years, and this has a magnified effect due to the increases in infrastructure funding. The construction industry is increasing spending at the rates displayed in Figure 1. Non-union and union craft workers must increase their members to effectively match this spending. Currently, the skilled craft worker numbers are failing to increase at this needed rate. The United States Bureau of Labor Statistics displayed in Figure 2 illustrates a dropin union membership rates by 2.9 million from 1985-2015 while the number of wage and salary workers grew from 88.3 million to 133.7 million. Consequently, the industry is experiencing a shortage of skilled trade workers. In a study by Seregl (2018), 91\% of 2,700 contractors and managers surveyed stated that they are experiencing difficulty finding and employing skilled craft workers. These individuals also expressed great concern that they do not foresee this challenge improving.

\section{Causes of Decreased Skilled Labor}

Contractors and unions are struggling to recruit and maintain skilled construction craft workers (Bureau of Labor Statistics, 2018). Several factors may contribute to this, such as low-wages, lack of technological advancements, societal influence, public perception, and the societal push for everyone 
Pilot Study for Understanding a Contributing Factor for a Decrease in ... W. Bender and B. Buckner

to attend college. A questionnaire was completed by $11^{\text {th }}$ and $12^{\text {th }}$ grade students to determine if these issues are the reasons young people are not considering the construction industry as a career.

Low wages have historically affected the construction industry (Kitroeff, 2017). Construction workers have built the nation's infrastructure, buildings, educational facilities and many other structures. According to the Bureau of Labor Statistics in May of 2017, men and women in the construction industry have not been financially rewarded for their services throughout history. This report showed that the average annual salary for a construction laborer is between $\$ 38,500$ and $\$ 40,420$ (Bureau of Labor Statistics, 2018). This salary is $\$ 12,686$ lower than the national average according to the household income reports from the census bureau conducted for 2017. The median earnings for a male working year round were reported to be $\$ 52,146$ a year with a total average household income of $\$ 77,713$ (U.S. Census Bureau, 2017). With the average salary of a construction worker being approximately $\$ 13,000$ lower than the average salary in the U.S., individuals may have little to no desire to become a construction worker.

The wages of construction workers have not increased at the same rate as other industries. The Los Angeles Times reported that Americans in the construction field make $\$ 5.00$ less an hour than they did in the 1970's, after the current adjustments for inflation. Figure 3 shows the loss of $\$ 5.00$ over the span of 43 years with inflation adjustments (Kitroeff, 2017).

\begin{tabular}{|c|c|c|c|}
\hline \multicolumn{4}{|c|}{ Union membership, 1983-2015 } \\
\hline Year & $\begin{array}{c}\text { Union } \\
\text { Membership Rate }\end{array}$ & $\begin{array}{l}\text { Union } \\
\text { members }\end{array}$ & $\begin{array}{l}\text { Wage/ } \\
\text { salary workers }\end{array}$ \\
\hline 1983 & 20.1 & $17,717,000$ & $88,290,000$ \\
\hline 1984 & 18.8 & $17,340,000$ & $92,194,000$ \\
\hline 1985 & 18 & $16,996,000$ & $94,521,000$ \\
\hline 1986 & 17.5 & $16,975,000$ & $96,903,000$ \\
\hline 1987 & 17 & $16,913,000$ & $99,303,000$ \\
\hline 1988 & 16.8 & $17,002,000$ & $101,407,000$ \\
\hline 1989 & 16.4 & $16,960,000$ & $103,480,000$ \\
\hline 1990 & 16 & $16,776,000$ & $104,876,000$ \\
\hline 1991 & 16 & $16,612,000$ & $103,723,000$ \\
\hline 1992 & 15.7 & $16,418,000$ & $104,668,000$ \\
\hline 1993 & 15.7 & $16,627,000$ & $106,101,000$ \\
\hline 1994 & 15.5 & $16,748,000$ & $107,989,000$ \\
\hline 1995 & 14.9 & $16,360,000$ & $110,038,000$ \\
\hline 1996 & 14.5 & $16,269,000$ & $111,960,000$ \\
\hline 1997 & 14.1 & $16,110,000$ & $114,533,000$ \\
\hline 1998 & 13.9 & $16,211,000$ & $116,730,000$ \\
\hline 1999 & 13.9 & $16,477,000$ & $118,963,000$ \\
\hline 2000 & 13.4 & $16,334,000$ & $122,089,000$ \\
\hline 2001 & 13.3 & $16,305,000$ & $122,229,000$ \\
\hline 2002 & 13.3 & $16,145,000$ & $121,826,000$ \\
\hline 2003 & 12.9 & $15,776,000$ & $122,358,000$ \\
\hline 2004 & 12.5 & $15,472,000$ & $123,554,000$ \\
\hline 2005 & 12.5 & $15,685,000$ & $125,889,000$ \\
\hline 2006 & 12 & $15,359,000$ & $128,237,000$ \\
\hline 2007 & 12.1 & $15,670,000$ & $129,767,000$ \\
\hline 2008 & 12.4 & $16,098,000$ & $129,377,000$ \\
\hline 2009 & 12.3 & $15,327,000$ & $124,490,000$ \\
\hline 2010 & 11.9 & $14,715,000$ & $124,073,000$ \\
\hline 2011 & 11.8 & $14,764,000$ & $125,187,000$ \\
\hline 2012 & 11.3 & $14,366,000$ & $127,577,000$ \\
\hline 2013 & 11.3 & $14,528,000$ & $129,110,000$ \\
\hline 2014 & 11.1 & $14,576,000$ & $131,431,000$ \\
\hline 2015 & 11.1 & $14,795,000$ & $133,743,00$ \\
\hline
\end{tabular}

Figure 2: Union Membership 
Pilot Study for Understanding a Contributing Factor for a Decrease in ... W. Bender and B. Buckner

\section{Hourly wages for U.S. construction workers}

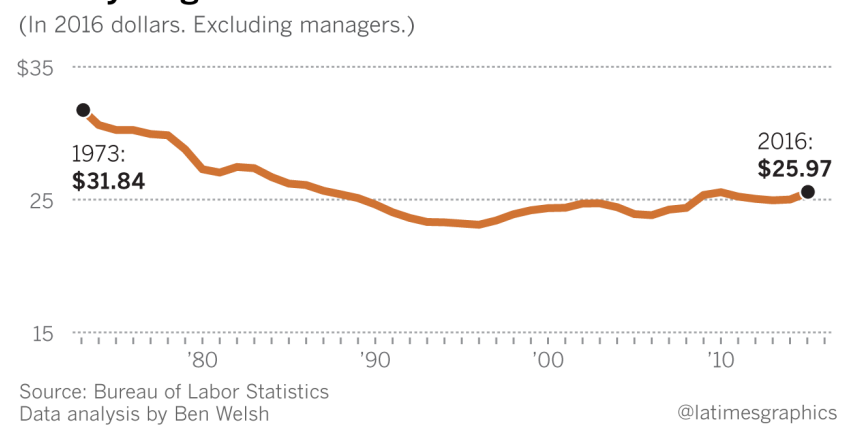

Figure 3: Hourly Wages

The construction industry has a huge backlog of work, yet there is a decrease in the number of skilled trade workers. If wages do not keep up with the national average, the skilled trade industry will continue to experience difficulty recruiting young adults to join the trades.

The lower hourly and annual salary rates for trade workers are pushing individuals to pursue management or positions in different fields. Most construction management positions, such as a project engineer or project manager, require a four-year college education. These management positions have a higher rate of pay. However, not all individuals have the desire, funding, or ability to pursue higher education.

Technology continues to play a large role in the shift of careers throughout society. The technology transformation began in the early 1990's when computers began being used to track, store and sort multiple forms of data for all types of businesses. Nearly all businesses now use computers, software, and servers as a foundational component of their company. As computer use began to grow, jobs were created to install, service and develop new programs and software for this industry. Some portions of the construction industry have been slow to adopt technology. While the field of technology is changing, the skilled construction training programs are unable to keep up with the technological advancements that are being implemented in the field of construction. If training programs are unable to advance as needed, business owners will be negatively impacted as they must re-train new apprentices for the new technology the company is using or procuring. Overall, the lag in training and the increase in wages within the field of technology have caused a notable decline in new skilled workers joining the construction industry (Abdol, Brown, \& Drummond, 1999).

In addition to wage gap issues and the low "technology attraction", societal influence, public perception, and the push for education may also be affecting young people's desire to become a skilled construction craftsperson. The negative perception of the construction industry has been around awhile. Traditionally, construction workers have been viewed by both young and older adults as rough, uneducated, and under-paid individuals that work in dangerous conditions.

The negative associations with construction workers are commonly conveyed through news outlets and also through conversations between parents and their children. Over time, parents have instilled in their children that one must attend college to have a rewarding career (Clarke \& Boyd, 2019). According to the Nation Center of Educational Statistics, college attendance has increased by $27 \%$ from the year 2000 to 2017. there has been an increase from 13.2 million students to 16.8 million with a projection of 17.2 million students by 2028 (The Condition of Education, 2019). 
Pilot Study for Understanding a Contributing Factor for a Decrease in ... W. Bender and B. Buckner

\section{Pilot Study Methodology}

To further understand what is causing young adults to steer away from the construction industry and join other professional careers, a pilot research study was conducted. The survey was developed using the following 11 questions: 1. What grade are you in? 2. Do you have older siblings (Yes/No)? If so please specify if they went to college and if not, what career did they chose? 3. Do you plan to attend college? 4. If you are attending college, what area will your studies focus on? 5. What made you chose to go or not go to college? 6. Do you plan to join the work force instead of college? 7. If so, what field? 8. Have you thought about joining a field in construction, such as an apprenticeship program? 9. Has your current place of instruction informed you about trade schools and or apprenticeship programs in the field of construction. 10. Would you be interested in learning about skilled construction apprenticeship programs? 11. Do you have any family members in the field of construction? If so, please specify their position.

The survey was conducted at a public high school located in Spokane, Washington. This location was chosen due to it being a public school and due to it having a diverse population. The survey was administered to the students by the teacher and was distributed to 53 students who were in $11^{\text {th }}$ and $12^{\text {th }}$ grade. 23 students were juniors $\left(11^{\text {th }}\right.$ grade $)$ and 30 students were seniors ( $12^{\text {th }}$ grade). The survey was conducted in three periods, in a general elective Environmental Science class which has an open enrollment process for all public-school students.

The survey was given to these students with no explanation as to the purpose of the study; this measure was taken to prevent potential skewing of data. This project should only be considered a pilot study for a small set of data conducted in one high school in one city of the country.

\section{Results and Analysis}

The focus of this analysis is to understand why this set of young adults are not joining construction and to better understand the societal pressures on 16 to 18 year-old students to pursue higher education. The results are compiled below in Figures 4 through 7.

The results show that students have many societal and parental pressures to pursue higher education following high school graduation. This is supported by question number three and figure 4. Question three asked the students if they plan to attend college after graduation with a follow-up question (number 5) as to why they will be attending college. 51 students said they do plan to attend college; 1 student's response was maybe and the other was no due to joining the military. $96 \%$ of the students within this research population plan to attend college.

What is causing $96 \%$ of these young adults to plan to attend college? The key factors contributing to this percentage are parental pressure and the pursuit of good careers, parental pressure and money. Figure 5 below indicates that the young adults are focused on attending college due to their desire to have a prosperous future. This figure also shows 18 individuals who indicated other reasons for planning to attend college. Specifically, sports, passion, future opportunities and other extracurricular activities were noted. The third largest contributing factor was parental pressure. This study also revealed money as a factor that influences students to attend college. This finding reinforces that students have been led to believe that college results in a successful career. 
Pilot Study for Understanding a Contributing Factor for a Decrease in ... W. Bender and B. Buckner

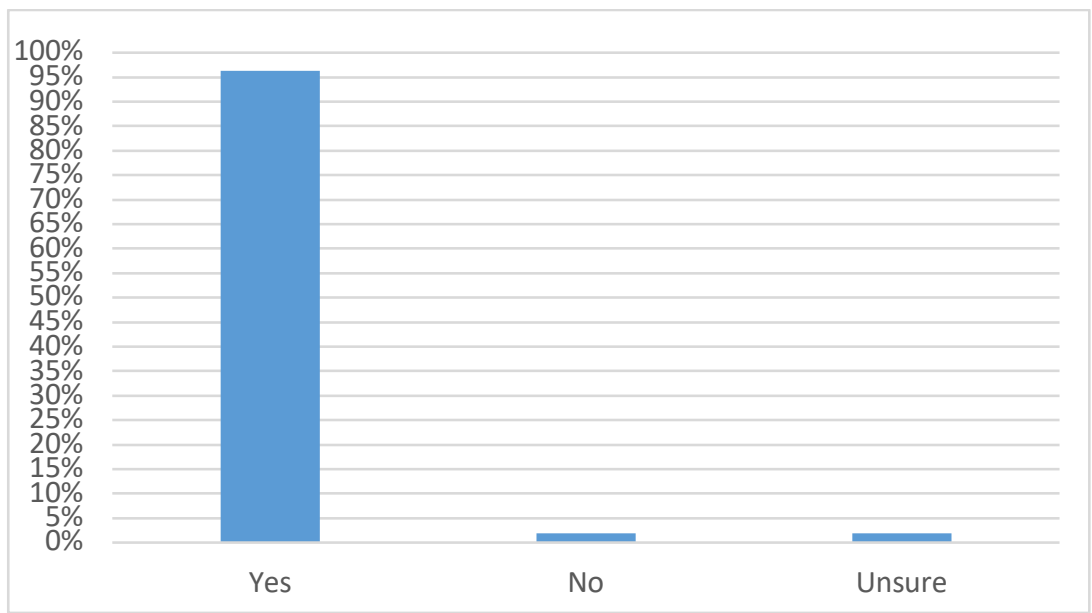

Figure 4: Students planning to attend college

Educational facilities may not be equipped to handle such high rates of attendance and many individuals will not be able obtain their bachelor's degree because they may not be accepted into colleges and universities. Some non-college bound students will be forced to join the service work force and may not understand the benefits associated with skilled trade apprenticeships and the longterm career opportunities that are associated with construction.

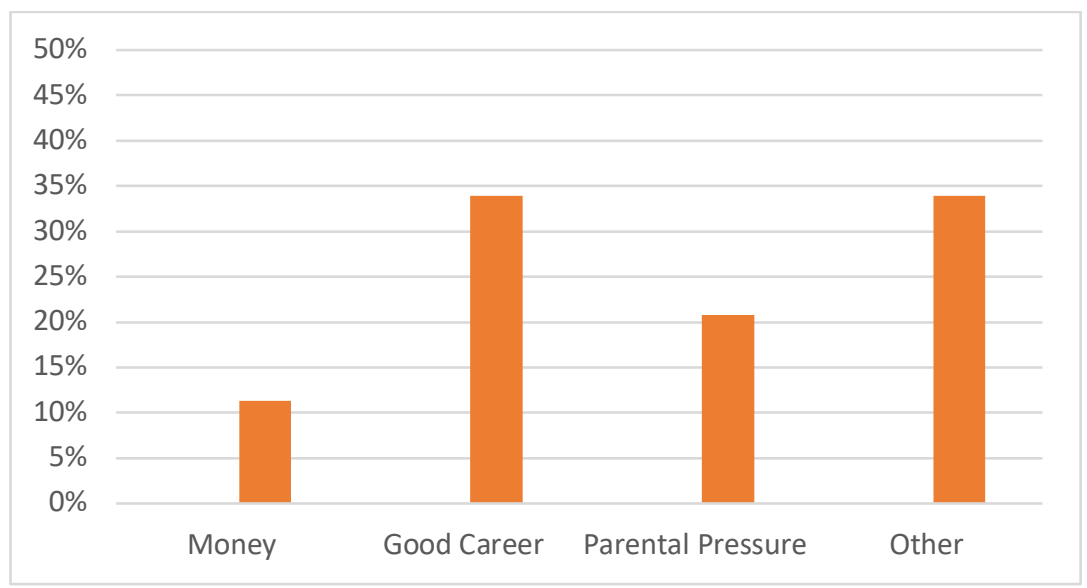

Figure 5: Why Attend College

As shown in Figure 6, about half of the 53 students stated that their high school has not educated them about skilled trade apprenticeship positions and opportunities following high school graduation. Additionally, as shown in figure 7,38 out of 53 students stated that they would be interested in learning about these opportunities. It is of great concern to see that parents and society are placing an emphasis on the importance of higher education, but are failing to inform students of the full spectrum of career options available to them following graduation. 
Pilot Study for Understanding a Contributing Factor for a Decrease in ... W. Bender and B. Buckner

Individuals who are not educated about the construction industry may want to learn about skilled trade positions and apprenticeship programs. Educating young adults about trade schools or apprentice programs may increase their interest in becoming members of the construction trades. Educating future generations that the construction industry and its workers are becoming technologically advanced and are financially competitive may appeal to high school students that are not interested in going to college.

\section{Skilled Construction Worker Recruitment}

With the current upturn in the building sector, the need for infrastructure improvements, combined with baby boomer retirements, the need for skilled construction laborers will continue to be an issue. In order to have enough trained workers across the industry, this issue needs both a short and longterm focus.

Most recruitment-related solutions can be easily implemented for contractors. First, contractors must retain their current skilled craft workers. With the industry boom, the competition for skilled craft workers is extremely high. Many construction company owners keep the individuals working or else they will lose them. If workers see that their current company does not have enough business in the pipeline, most will leave the company to ensure they stay working. Another solution to retain their current staff is to offer incentives. These incentives should include competitive hourly wages, travel bonuses, and events to recognize and appreciate their hard work. Out of these three items, competitive hourly wages are of probably the most importance to employees. Owners should perform an annual analysis to see where their hourly wages are in comparison to the market and their direct competitors.

The survey results shown in Figures 6 and 7 further establish that proper recruitment is not being conducted prior to students making the decision about a career in construction. In order to recruit new employees, young people must first be educated about the benefits of working in construction. This education must begin at a young age in order to prove to young adults that construction workers are highly paid and have rewarding careers.

Parents and the media play a critical role in the delivery of these teachings and the formation of public perceptions. As these young individuals are being brought up through the public education system, the next step in this process is to properly explain these opportunities to students. Public schools must inform students of their post high school career choices while elaborating on the pros and cons of each option. The opportunity to educate students on trade schools must become as widespread as that of college education. When higher education is discussed as the only career opportunity for students, alternative career possibilities will not be explored (Chini, Brown, and Drummond, 1999). 
Pilot Study for Understanding a Contributing Factor for a Decrease in ... W. Bender and B. Buckner

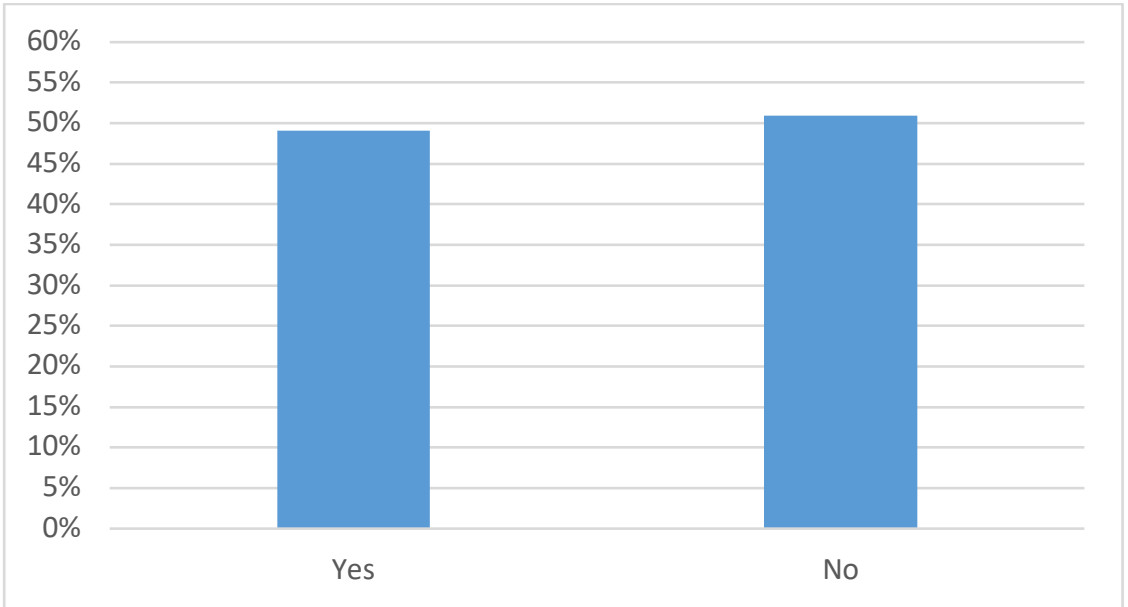

Figure 6: Have you been informed about Construction Careers?

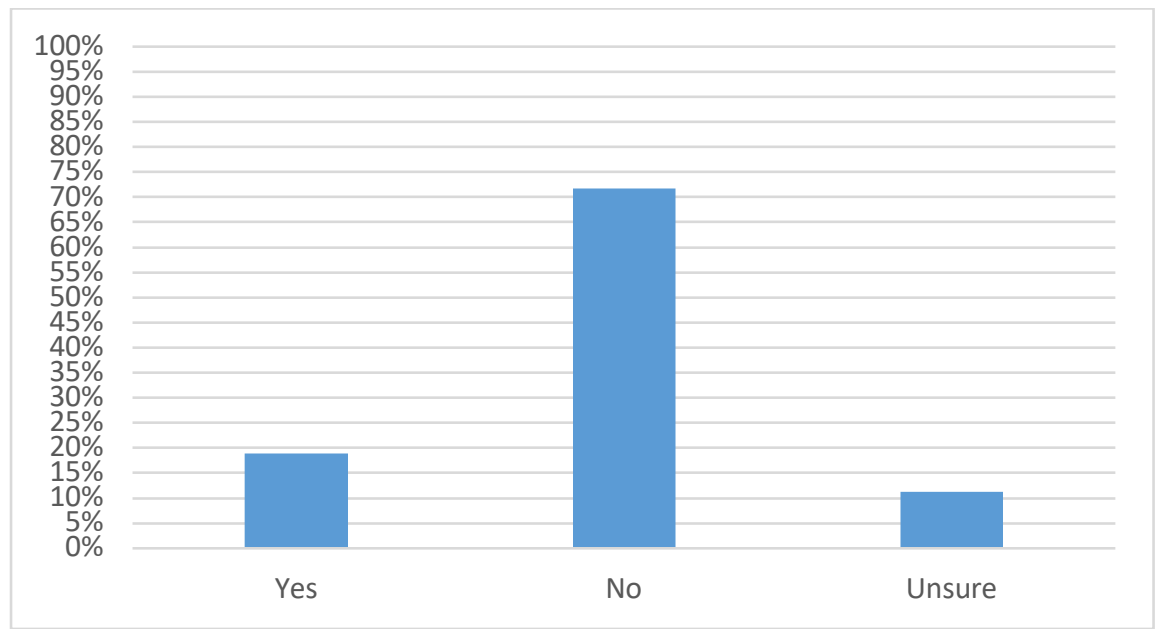

Figure 7: Interested in Learning About Construction Careers?

To implement these recommendations construction companies, owners, educational institutions, and unions must step in and educate young adults about the construction industry and aid in correcting the public's misconceptions about the trades. The training programs must stay current and apply new technologies that will make the industry more appealing to young people. Many new technological programs are available for office and field use. As today's society continues to rely on progressive technology, younger generations are becoming more intrigued about increasing their knowledge of technology (Construction Image Crisis, 2018). When training programs and industry owners become tech-friendly, public perceptions will shift and there will be a greater focus on educating the young adult work force about construction which will result in an influx of workers into the construction industry. 
Pilot Study for Understanding a Contributing Factor for a Decrease in ... W. Bender and B. Buckner

\section{Conclusion}

Billions of dollars will be spent on infrastructure and a portion of these funds should be invested into recruiting and training the craft workers who will build the projects. The lack of skilled construction trade workers is being felt throughout the industry with no apparent change on the horizon in this trend.

Young adults who are poised to graduate from high school within the next two years have indicated in a pilot study that higher education is the most important career choice. In this pilot study, 51 of the 53 students plan to attend college due to parental pressures and the desire for a successful career. The pilot study has indicated that construction is viewed as a non-technical, low paying career with littleto-no opportunity for growth or advancement. Thus, young adults do not view this field as an avenue for as a successful career. The pilot study indicated that these young adults do not consider the construction industry due to a lack of education, information, and recruitment. The students have not been properly educated on the career opportunities and subsequent financial benefits that the skilled trades offer. These indicators and issues will cause another decline in skilled construction labor for many years to come. The current skilled construction labor generation is retiring at an increased rate, leaving many positions unfilled. In order to effectively replace the current generation of skilled craft workers, society, unions, parents and public education must take a proactive role in workforce development. The interests of the younger generation have changed from hands-on learning to computer-based learning and technology. The industry must keep up with the current technological advances in order to recruit young adults interested in construction and technology. Without these changes, the industry will never effectively replace the individuals retiring and our infrastructure will lack the needed resources to complete these projects.

\section{Recommendations}

This pilot was limited due to having a small data set that was derived from a single location. This small data set that was created from a single location, has informed the authors of specific questions to ask in future studies. In order to minimize these limitations and to have a heightened understanding of the current issue at hand, future studies to collect data from a larger, more diverse samples are required. The authors plan to do this during a event where over 1,500 high school students from numerous school districts attend a construction career day. We plan to conduct this survey before and after the day's event.

Expanding the research to numerous locations with varying demographics would yield a better understanding of what is causing young adults to choose higher education or other career choices over the field of construction. As the construction industry expands, a lack of skilled construction labor will continue to increase. This increasing labor shortage will ultimately necessitate the need to further investigate the factors that are contributing to the labor shortage that construction companies are experiencing. 
Pilot Study for Understanding a Contributing Factor for a Decrease in ... W. Bender and B. Buckner

\section{References}

Bureau of Labor Statistics. (2018). URL https://www.bls.gov/news.release/union2.nr0.htm.

Braunstein, A. (2001). Work Experience: Determinant of MBA Academic Success, Proceedings of the Annual Meeting of the American Statistical Association, Atlanta, GA, USA.

Chini, A. R., Brown, B. H., \& Drummond, E. G. (1999, April 7). Causes of the Construction Skilled Labor Shortage and Proposed Solutions. [ASC Proceedings of the 35th Annual Conference]. URL http://ascpro0.ascweb.org/archives/1999/chini99.htm.

Clarke, S. M., \& Boyd, B. J. (2019, May). Youths' Perceptions of the Construction Industry: An Analysis at the Elementary, Middle, and High School Levels. [Association Schools of Construction] URL http://ascpro0.ascweb.org/archives/cd/2011/paper/CPGT342002011.pdf.

Construction Spending. (2018, July). [Construction Analytics]. URL https:/edzarenski.com/2018/09/04/construction-spending-jul-2018/.

Construction's Image Crisis, Why and How Construction Needs to Attract Youth. (2018, September 11). [Unearth Labs]. URL https://unearthlabs.com/blog/construction-management/constructionimage-crisis/.

Makridakis, S., Wheelwright, S.C., and Hyndman, R.J. (2008), Forecasting: Methods and Applications, Wiley, New Jersey

Kitroeff, N. (2017, April 22). Construction workers in L.A. make less now than 40 years ago. Here's why. [LA Times]. URL https://www.latimes.com/projects/la-fi-construction-trump/.

Rebuilding Americas Infrastructure. (2019, January). [White House]. URL https://www.whitehouse.gov/wp-content/uploads/2018/02/FY19-Budget-Fact-Sheet_InfrastructureInitiative.pdf.

Sergel, A. (2018, June 15). Where Have All the Builders Gone? [US News and World Report]. URL https://www.usnews.com/news/the-report/articles/2018-06-15/the-us-construction-industry-isbooming-but-where-are-the-builders.

The Condition of Education - Postsecondary Education - Postsecondary Students - Undergraduate Enrollment - Indicator. (2019, May 1). [Nation Center for Education Statistics]. URL https://nces.ed.gov/programs/coe/indicator_cha.asp.

US Census Bureau. (2017). Income and Poverty in the United States: 2017. URL

https://www.census.gov/library/publications/2018/demo/p60-263.html. 